\title{
Research on Urban Logistics Competitiveness in Fujian Province Based on Factor Analysis and Cluster Analysis
}

Hongmao $\mathrm{Wei}^{1}$

Fujian Polytechnic of Information Technology, Fuzhou City, Fujian Province, China

\begin{abstract}
As an important province in the southeast coastal area, Fujian is composed of 9 cities. Due to various economic, political and geographical influences, the logistics development of these cities is uneven. Based on the analysis of the factors affecting the competitiveness of urban logistics, this paper establishes the evaluation index system of urban logistics competitiveness. Factor analysis is used to evaluate the logistics competitiveness index of each city in Fujian Province, and the comprehensive score and ranking of the logistics competitiveness of each city are obtained. Cluster analysis is used to divide 9 cities in Fujian into 4 categories, and the reasons for the results are analyzed
\end{abstract}

Keywords: Fujian province; Urban logistics; Competitiveness; Factor analysis; Cluster analysis.

\section{The competitiveness of urban logistics}

\subsection{The connotation of the competitiveness of urban logistics}

Urban logistics refers to the dynamic process of serving the needs of urban economic development, the physical flow of goods within the city, the collection and distribution of goods between the city and the outside region, and the clearance of urban waste. The competitiveness of urban logistics refers to the competitive ability of urban logistics industry to compete for logistics resources, to occupy logistics market, to expand logistics power and to gain momentum of growth.

\subsection{Factors affecting the competitiveness of urban logistics}

As the factors affecting the competitiveness of urban logistics have not been clearly defined at home and abroad, based on field research and relevant literature, the factors of urban logistics competitiveness with high recognition degree are summarized and compared. The influencing factors can be divided into five categories, namely, the scale of urban logistics, the current logistics resources of logistics, the demand for urban logistics, the level of urban macroeconomic development, and the level of urban informatization and talents.

\subsubsection{Urban logistics scale}

The scale of urban logistics is a standard to measure the development of urban logistics industry, and is one of the important factors to evaluate the competitiveness of a city's logistics. The scale of urban logistics can also be measured by the total quantity of goods, turnover, express delivery business and the added value of the logistics industry. The total quantity of goods shows that the number of logistics industry work and the turnover of goods comprehensively reflect the total amount and distance of transportation, and the volume of express delivery can also reflect the development degree of urban logistics industry and the added value of logistics industry reflects the value created by the logistics industry.

\subsubsection{Urban logistics resources}

Urban logistics resources are the necessary guarantee to maintain the normal operation of the urban logistics industry, and also the basis of a city's logistics competitiveness. The total amount of investment, employees, miles of logistics (kilometers, railways), the number of vehicles, ships and other tools, the number of logistics enterprises, the number of logistics parks and so on can all be called the logistics resources of a city.

\subsubsection{Urban logistics demand}

Logistics demand is a kind of derivative demand. There is a strong correlation between urban logistics demand and urban economy, and it has a great influence on the competitiveness of urban logistics. The total volume of imports and exports and the total retail sales of social

${ }^{1}$ Fund project: Supported by Program for New Century Excellent Talents in Fujian Province University. Wei Hongmao (1979-), Male, Zhouning, Fujian, Master, Associate Professor, Research direction: Research on Regional Logistics 
consumer goods reflect the logistics demand of a city from the side.

\subsubsection{Urban macroeconomic development level}

The development of urban logistics is closely related to the development of urban economy. Only the prosperity of urban economy can promote and improve the development level of urban logistics. With the improvement of urban economy, the logistics transportation between various industries will increase, thus promoting the development of logistics industry. Therefore, the economy is the key material guarantee for the development of logistics industry and the upgrading of urban logistics competitiveness. We can see the current situation of a city's economic development through its GDP, GDP growth rate and consumption level.

\subsubsection{Urban informationization and talent level}

In the "Internet + " era, the development of urban logistics industry can not be separated from the support of information technology, as well as excellent management concepts and mature operation technology. Modern logistics requires excellent management and technical talents in all aspects. It needs to be able to control the complete logistics process, with professional knowledge theory and new talents with a highly strategic vision. Talents are the high-quality resources for competition. The more talented people are, the stronger their competitiveness. Therefore, the urban logistics industry can strengthen the talent reserve resources to improve the economic competitiveness of urban logistics.

\section{Evaluation index system of urban logistics competitiveness}

Improving and perfecting the evaluation index system of urban logistics competitiveness has the important significance of enhancing self-awareness, optimization and upgrading. According to the reasons that affect the competitiveness of urban logistics, the evaluation system of urban logistics competitiveness is established (Table 1).

Table 1 The index system of urban logistics competitiveness

\begin{tabular}{|c|c|c|}
\hline \multicolumn{2}{|c|}{ First level index } & \multirow{2}{*}{$\begin{array}{l}\text { Second level index } \\
\mathrm{X}_{1} \text { Total volume of goods (ten } \\
\text { thousand tons) }\end{array}$} \\
\hline $\begin{array}{l}\text { Urban } \\
\text { scale }\end{array}$ & logistics & \\
\hline $\begin{array}{l}\text { Urban } \\
\text { resources }\end{array}$ & logistics & $\begin{array}{l}\mathrm{X}_{2} \text { Total investment in } \\
\text { transportation, storage and post } \\
\text { industry (100 million yuan), } \mathrm{X}_{3} \\
\text { Logistics mileage (kilometer), } \mathrm{X}_{4} \\
\text { A-level logistics enterprises (one) }\end{array}$ \\
\hline $\begin{array}{l}\text { Urban } \\
\text { demand }\end{array}$ & logistics & $\begin{array}{l}X_{5} \text { Added value of transportation, } \\
\text { storage and post industry, } X_{6} \text { Total } \\
\text { retail sales of social consumer goods } \\
(10000 \text { yuan) }\end{array}$ \\
\hline
\end{tabular}

\begin{tabular}{l|l}
$\begin{array}{l}\text { Urban } \\
\text { macroeconomic } \\
\text { development level }\end{array}$ & $\mathrm{X}_{7}$ GDP (100 million yuan) \\
\hline $\begin{array}{l}\text { Urban logistics } \\
\text { informationization } \\
\text { and talent level }\end{array}$ & $\begin{array}{l}\mathrm{X}_{8} \text { number of students in logistics } \\
\text { majors in ordinary universities } \\
\text { (person) }\end{array}$ \\
\hline
\end{tabular}

\section{Research on urban logistics competitiveness in Fujian province}

\subsection{Research cities and data sources}

Fujian province is located in the southeast of China, the shore of the East China Sea, the east facing the sea, the Taiwan province across the sea, the Pearl River Delta and the Yangtze River Delta connecting Guangdong province in the southwest, Jiangxi Province on the west, Lishui and Wenzhou in the northeast of Zhejiang province. Fujian province is the second largest coastal region in China, with a length of 3,752 kilometers, making it very convenient to go to sea. It can be seen that the development area and transportation network of Fujian Province have great advantages. It can be said that it is one of the provinces with superior logistics conditions and is also an important province under the "One Belt, One Road" strategy. This paper mainly analyzes nine cities in Fuzhou and Xiamen, the main cities in Fujian Province. The basic data (Table 2) is mostly derived from the 2017 China Urban Statistical Yearbook, with individual data from other sources. For example, the data of $\mathrm{X}_{4}$ is the number of logistics enterprises above grade $\mathrm{A}$ in each city of Fujian province. The data are from the official website of Fujian Provincial Department of Commerce as at the end of 2017. The data of X8 are the number of students majoring in logistics in colleges and universities in Fujian. Data are collected from the school enrollment prospectus in recent years, so all data sources are reliable, and the results are also available.

\subsection{Factor analysis}

\subsubsection{Factor index analysis}

The software SPSS19 is used for factor index analysis. The main operation is to process the data according to the standard and eliminate the different dimensions.

\subsubsection{Adaptive test}

The KMO test is used to check the partial correlation between variables. The KMO value that can carry out factor analysis is between 0.5-0.9. Once the scope is exceeded, the result will be affected. After the adaptive test, the correlation between variables is found in this paper, and the KMO value is within the range of 0.5-0.9. Therefore, factor analysis can be continued. In addition, through Bartlett's spherical test, it is found that the Sig value is 0 . In the test standard, if the Sig value is less than 0.05 , it means that there is a correlation between the variables of the test, then the Sig value of this test is 0 , 
which proves that there is a kinship between the variables, so the factor can be analyzed.

\subsubsection{Factor analysis result}

The first 2 factors are extracted by using the extraction principle with the characteristic value greater than 1 , and the cumulative variance is $87.835 \%$. It is proved that these 2 factors contain most of the index information, and the factor extraction effect is very good.

Table 3-2 The rotated component matrix ${ }^{\text {a }}$

\begin{tabular}{|l|l|l|}
\hline & \multicolumn{2}{|l|}{ Component } \\
\cline { 2 - 3 } & 1 & 2 \\
\hline $\begin{array}{l}\text { GDP (100 million yuan) } \\
\text { Total amount of goods (ten thousand } \\
\text { tons) }\end{array}$ & .974 & -.130 \\
$\begin{array}{l}\text { Number of students in ordinary } \\
\text { universities (person) }\end{array}$ & .908 & .246 \\
$\begin{array}{l}\text { Added value of transportation, } \\
\text { storage and post industry (ten } \\
\text { thousand yuan) } \\
\begin{array}{l}\text { Total fixed assets investment (100 } \\
\text { million yuan) }\end{array}\end{array}$ & .905 & -.025 \\
$\begin{array}{l}\text { The number of logistics enterprises } \\
\text { (one) }\end{array}$ & .794 & .404 \\
$\begin{array}{l}\text { Total retail sales of social consumer } \\
\text { goods (ten thousand yuan) } \\
\text { Road mileage (kilometer) }\end{array}$ & .785 & .058 \\
\hline
\end{tabular}

It can be seen from the rotated component matrix (Table 3-2) that the first factor has a large load on the 7 variables of GDP, total amount of goods, number of students in ordinary universities, added value of transportation, storage and post industry, total fixed asset investment, number of logistics enterprises and total retail value of social consumer goods. The second factor has a large load on the road mileage variable.

Table 3-3 Component score coefficient matrix

\begin{tabular}{|c|c|c|}
\hline & \multicolumn{2}{|c|}{ Component } \\
\cline { 2 - 3 } & 1 & 2 \\
\hline Total amount of goods (ten thousand \\
tons) $\mathrm{X}_{1}$ & .161 & .053 \\
Total fixed assets investment (100 million & & \\
yuan) $\mathrm{X}_{2}$ & .128 & .183 \\
Road mileage (kilometer) $\mathrm{X}_{3}$ & .139 & -.769 \\
The number of logistics enterprises (one) & .095 & .257 \\
$\mathrm{X}_{4}$ & & \\
Added value of transportation, storage \\
and post industry (ten thousand yuan) $\mathrm{X}_{5}$ \\
Total retail sales of social consumer \\
goods (ten thousand yuan) $\mathrm{X}_{6}$ & .191 & -.152 \\
GDP (100 million yuan) $\mathrm{X}_{7}$ & .154 & -.069 \\
$\begin{array}{c}\text { Number of students in ordinary } \\
\text { universities (person) } \mathrm{X}_{8}\end{array}$ & .166 & -.245 \\
\hline
\end{tabular}

Based on the table above, the scores for each factor are calculated as follows:

$\mathrm{F} 1=0.161 \mathrm{X}_{1}+0.128 \mathrm{X}_{2}+\ldots \ldots+0.166 \mathrm{X}_{8}$

$\mathrm{F} 2=0.053 \mathrm{X}_{1}+0.183 \mathrm{X}_{2}+\ldots \ldots-0.012 \mathrm{X}_{8}$
According to the principal factor variance contribution rate after the table rotation, the principal component synthesis model of each common factor weight is constructed, and then the comprehensive score of urban logistics competitiveness is obtained:

\section{$\mathrm{Z}=0.79 \mathrm{~F} 1+0.210 \mathrm{~F} 2$}

By substituting the values of F1 and F2 into the above formula, a comprehensive score of urban logistics competitiveness can be obtained.

\subsection{Cluster Analysis}

\subsubsection{Clustering method}

According to the comprehensive score of urban logistics competitiveness, the logistics competitiveness of nine cities in Fujian Province is divided into four categories, which are very strong, strong, general and weak.

\subsubsection{Cluster analysis result}

Table 4 Cluster analysis result

\begin{tabular}{|c|c|}
\hline Category & City \\
\hline Very strong & Fuzhou, Xiamen, Quanzhou \\
\hline Strong & Zhangzhou \\
\hline General & Putian, Sanming, Longyan \\
\hline Weak & Nanping, Ningde \\
\hline
\end{tabular}

The first category is cities with very strong logistics competitiveness - Fuzhou, Xiamen and Quanzhou. It can be seen that the first factor scores of the above three cities also rank in the top three. Their common features include developed urban economy, high income and consumption level.

From Table 3-4, it can be seen that Fuzhou Logistics has the strongest competitiveness, with a score of 1.29 , of which the first main factor score is 1.67 , which is much higher than other cities, which is the first reason for Fuzhou to rank first.

The second category is Zhangzhou, a city with strong logistics competitiveness. It can be seen that the scores of the first factor and the second factor in Zhangzhou are also relatively advanced, and the urban economic level, income and consumption level are relatively high. Therefore, from the point of view of logistics demand, the logistics demand in Zhangzhou is also relatively vigorous, which leads to the development of its logistics industry, and makes its logistics competitiveness stronger.

The third category is Putian, Sanming and Longyan, which are generally competitive in logistics. It can be seen that Putian's second factor score is second, the urban road mileage has a high contribution, indicating that Putian has the potential to develop the logistics industry, but the economic aspect is relatively weak. People's living standards limit the demand for logistics, and the business is not as developed as Quanzhou, because the competitiveness of the logistics is general.

The fourth category is cities with weak logistics competitiveness - Nanping and Ningde. It can be seen 
that Ningde's second factor score is third, but the first factor score is ninth, indicating that the city's economic ability is poor, and the logistics facilities are not perfect. The location in the southwest is not enough, the resources are less, and the economic base level is also low.

\subsection{Conclusion}

This paper compares the logistics competitiveness of nine big cities in Fujian Province and obtains the ranking of the competitiveness of each city. These rankings are consistent with the official rankings of Fujian Province, proving that the eight index as a reference for the evaluation system is correct. In addition, the logistics competitiveness of 9 cities is divided into 4 categories by clustering method. The specific conditions are listed in Table 4. Among them, the most competitive cities are Xiamen, Quanzhou and Fuzhou. The weakest logistics competitiveness is Nanping and Ningde.

The conclusion of data analysis combined with the collected information is as follows:

\subsubsection{The competitiveness of urban logistics is greatly affected by the location, and the space is "high in the southeast and low in the northwest"}

Fujian has a long coastline and many important cities have obvious coastal advantages. In addition, these cities are located in the developed coastal areas with better economic foundation, perfect infrastructure construction, advanced information technology, goods storage, packaging, transport, loading and unloading equipment. Especially, the coastal logistics port scale is increasing, greatly improving the competitiveness of Fujian's urban logistics. At present, the volume of goods transported through Fujian port accounts for $90 \%$ in the province and $85 \%$ in China (container), of which Fuzhou and Xiamen are one of the most important port logistics foundations in China.

\subsubsection{Urban economy is the basis of logistics competitiveness}

The economy is an important material support for the development of logistics, and logistics is an indispensable part of economic development. Fujian Province's economic development is fast and stable, and the province's GDP has maintained a sustained high development in recent years, laying a solid foundation for the development of the province's logistics industry. Fuzhou and Xiamen are benefiting from the rapid development of the economy and become the most competitive cities in the province. Economic development will inevitably lead to the improvement of urban living standards. People's pursuit of material will lead to a strong demand for logistics, and demand will drive development. By giving investment support to the logistics industry and cultivating relevant professionals, the development of the entire industry will be promoted, and the competitiveness of logistics will be continuously strengthened.

\subsubsection{The leading role of regional leading enterprises has provided development experience for enterprises of all sizes}

In the past twenty years, Fujian province has seen a number of leading enterprises in the logistics industry. These enterprises have summed up a set of experience in developing and expanding the logistics industry in terms of total output value, enterprise scale and operation. Relevant small enterprises can learn from the experience of these enterprises, copy their models and improve their own ability to develop logistics. At present, Fujian Province has a number of leading enterprises in the logistics field, and some are famous throughout the country's logistics industry, such as Shenghui Fujian Logistics Company, Fujian Rongtai Logistics Company, Fujian Transportation Group Co., Ltd. and Xiamen Port, etc. Some are state-owned enterprises, some are private enterprises, and have strong logistics competitiveness both inside and outside the province. Through the data in Table 2, it can be seen intuitively that the number of logistics enterprises above grade $\mathrm{A}$ in each city. The competitiveness of a city's logistics is also greatly dependent on a leading role of leading enterprises, driving the development of the entire industry, forming a strong competitive position, matching the number of logistics with economic development, and promoting the promotion of logistics competitiveness.

\section{References}

1. Tan Guanyin, Zuo Zeping. The Dynamic Comparison of the City Logistics Competitiveness in the Economic Zone of West Taiwan Strait [J]. Economic Geography, 2012, 32(3): 107-113.

2. National Bureau of Statistics. City Social and Economic Investigation Division. 2017 China City Statistical Yearbook [M]. Beijing: China Statistics Press, 2017.

3. Chen Ping. Analysis of the Development of Modern Logistics Industry in Xiamen[J]. Logistics Science and Technology, 2014, (2): 62-67.

4. Wei Jigang, Zhao Fujun. "One Belt, One Road" Construction and New Opportunities for China's International Logistics [J]. China Logistics \& Purchasing, 2015 (23): 68-69.

5. Ye Yan. Status Analysis Logistics Industry Fujian Province Speeding up Its Development [J]. Value Engineering, 2014, 36: 112-118.

6. Zhang Ling. Cluster Analysis and Evaluation of Logistics Competitivity of Cities in Shandong Province [J]. Logistics Technology, 2014, 33(9): 286-289.

7. Yang Yanping, Liu Hui. On the Spatial Difference and Functional Orientation of Urban Logistics Competitiveness in Henan Province [J]. Journal of Henan University of Technology, 2016, 12(4): 47-56. 
Table 2 Index data of 9 cities in Fujian Province in 2016

\begin{tabular}{|c|c|c|c|c|c|c|c|c|}
\hline & $\begin{array}{l}\text { Total amount of } \\
\text { goods (ten } \\
\text { thousand tons) }\end{array}$ & $\begin{array}{c}\text { Total fixed } \\
\text { assets } \\
\text { investment } \\
\text { (100 million } \\
\text { yuan) }\end{array}$ & $\begin{array}{c}\text { Road } \\
\text { mileage } \\
\text { (kilometer) }\end{array}$ & $\begin{array}{l}\text { The number } \\
\text { of logistics } \\
\text { enterprises } \\
\text { above A } \\
\text { level (one) }\end{array}$ & $\begin{array}{l}\text { Added value } \\
\text { of } \\
\text { transportation, } \\
\text { storage and } \\
\text { post industry } \\
\text { (ten thousand } \\
\text { yuan) }\end{array}$ & $\begin{array}{l}\text { Total retail } \\
\text { sales of social } \\
\text { consumer } \\
\text { goods (ten } \\
\text { thousand } \\
\text { yuan) }\end{array}$ & $\begin{array}{c}\text { GDP (100 } \\
\text { million } \\
\text { yuan) }\end{array}$ & $\begin{array}{c}\text { Number of } \\
\text { students in } \\
\text { logistics } \\
\text { majors in } \\
\text { ordinary } \\
\text { universities } \\
\text { (person) }\end{array}$ \\
\hline Fuzhou & 25494.54 & 487.26 & 11408 & 53 & 2525898 & 37631418 & 6197.64 & 3240 \\
\hline Xiamen & 27108.27 & 500.08 & 2197 & 88 & 2833197 & 12834596 & 3784.27 & 1260 \\
\hline Putian & 5464.79 & 271.58 & 6388 & 15 & 676149 & 6231302 & 1823.43 & 135 \\
\hline Sanming & 9288.39 & 234.82 & 14915 & 11 & 1090700 & 4806339 & 1860.82 & 180 \\
\hline Quanzhou & 24593.15 & 414.53 & 17526 & 85 & 4206504 & 10980568 & 6646.63 & 1575 \\
\hline Zhangzhou & 9345.41 & 282.17 & 12200 & 21 & 1759655 & 8755936 & 3125.35 & 315 \\
\hline Nanping & 3410.98 & 140.6 & 15622 & 7 & 513980 & 5566788 & 1459.79 & 315 \\
\hline Longyan & 8281.18 & 186.17 & 14314 & 14 & 1110874 & 7290015 & 1895.67 & 135 \\
\hline Ningde & 4450.94 & 160.84 & 11569 & 11 & 774893 & 5123472 & 1623.11 & 135 \\
\hline
\end{tabular}

Table 3-1 interpretation of total variance

\begin{tabular}{|c|c|c|c|c|c|c|c|c|c|}
\hline \multirow[b]{2}{*}{ Component } & \multicolumn{3}{|c|}{ Initial eigenvalue } & \multicolumn{3}{|c|}{ Extraction of load square sum } & \multicolumn{3}{|c|}{ Sum of squared rotational loads } \\
\hline & Total & $\begin{array}{l}\text { Percentage } \\
\text { of variance }\end{array}$ & $\begin{array}{c}\text { Cumulative } \\
\%\end{array}$ & Total & $\begin{array}{l}\text { Percentage } \\
\text { of variance }\end{array}$ & $\begin{array}{c}\text { Cumulative } \\
\%\end{array}$ & Total & $\begin{array}{l}\text { Percentage } \\
\text { of variance }\end{array}$ & $\begin{array}{c}\text { Cumulative } \\
\%\end{array}$ \\
\hline 1 & 5.803 & 72.544 & 72.544 & 5.803 & 72.544 & 72.544 & 5.553 & 69.415 & 69.415 \\
\hline 2 & 1.223 & 15.292 & 87.835 & 1.223 & 15.292 & 87.835 & 1.474 & 18.420 & 87.835 \\
\hline 3 & .817 & 10.214 & 98.049 & & & & & & \\
\hline 4 & .108 & 1.352 & 99.401 & & & & & & \\
\hline 5 & .030 & .379 & 99.780 & & & & & & \\
\hline 6 & .015 & . 188 & 99.968 & & & & & & \\
\hline 7 & .002 & .028 & 99.996 & & & & & & \\
\hline 8 & .000 & .004 & 100.000 & & & & & & \\
\hline
\end{tabular}

Table 3-4 Urban logistics competitiveness and rankings

\begin{tabular}{|l|c|c|c|c|c|c|}
\hline City & F1 & Ranking & F2 & Ranking & $\begin{array}{c}\text { Urban logistics } \\
\text { competitiveness }\end{array}$ & Ranking \\
\hline Fuzhou & 1.67 & 1 & -0.13 & 4 & 1.29 & 1 \\
\hline Xiamen & 0.73 & 3 & 2.19 & 1 & 1.03 & 2 \\
\hline Putian & -0.86 & 8 & 0.93 & 2 & -0.49 & 5 \\
\hline Sanming & -0.52 & 5 & -0.47 & 6 & -0.51 & 6 \\
\hline Quanzhou & 1.38 & 2 & -1.20 & 9 & 0.84 & 3 \\
\hline Zhangzhou & -0.14 & 4 & -0.14 & 5 & -0.14 & 4 \\
\hline Nanping & -0.81 & 7 & -0.63 & 8 & -0.77 & 9 \\
\hline Longyan & -0.58 & 6 & -0.51 & 7 & -0.57 & 7 \\
\hline Ningde & -0.87 & 9 & -0.02 & 3 & -0.69 & 8 \\
\hline
\end{tabular}

